\title{
DO INDUSTRIES INFLUENCE GOVERNMENT REGULATORY AGENCIES?
}

\author{
HOW MUCH INFLUENCE DO INDUSTRIES HAVE OVER THE REGULATORY \\ AGENCIES RESPONSIBLE FOR POLICING THESE SAME INDUSTRIES? THIS \\ IS WHAT DR EVA HEIMS AT THE UNIVERSITY OF YORK IS HOPING TO \\ DISCOVER, AND IT MAY BE LESS THAN THE MEDIA WOULD HAVE US BELIEVE
}

\section{TALK LIKE A POLITICAL SCIENTIST}

CAPTURE - the idea that an agency that is supposed to act for the good of all society is excessively influenced (captured) by one particular group

\section{INDUSTRY INFLUENCE - when}

individual companies or industrial sectors (e.g. the energy or finance industries) are able to influence government decisions

POLITICAL SCIENTIST - a researcher who studies an aspect of politics, such as how governments work or how policies are made
POLITICIAN - a person elected (or seeking to be elected) by the public to work in the government

\section{REGULATORY AGENCY - a government} institution responsible for monitoring a sector of public life, usually to protect the public from unsafe products and business practices

REVOLVING DOOR - the movement of individuals between industry jobs and related jobs in government
Regulatory agencies are the government institutions responsible for monitoring a wide range of activities in the UK, to ensure that the public is treated safely and fairly.

Your school will be inspected by Ofsted and your exams will be monitored by Ofqual to check that all candidates are fairly assessed. The Civil Aviation Authority ensures that planes are safe to fly, the Food Standards Agency checks that food is safe to eat, Ofgem determines the maximum price that energy companies can charge us for electricity and gas, and the Environment Agency monitors our water quality.
Most of the time, we are unaware of the decisions made by regulatory agencies, despite the fact that they have such an impact on our daily lives. But public awareness has recently increased as a result of the COVID pandemic, when the process of creating vaccines has been at the forefront of the news. Once a laboratory has developed a vaccine, it must be approved by the Medicines and Healthcare products Regulatory Agency (MHRA), which is responsible for ensuring that the vaccine is safe and effective, before it is administered to the public. Different countries have their own regulatory bodies to monitor activities. For example, the Food and Drug Administration (FDA) was responsible for approving the COVID vaccines in the USA, while the European Medicines Agency (EMA) approved them in the EU.

"These regulatory agencies are in charge of very important issues that affect all of us," explains Dr Eva Heims of the University of York. "However, unlike politicians in cabinet or parliament, they are not elected by the public, but are recruited on the basis of their professional expertise."

WHAT IS THE PROBLEM WITH

UNELECTED REGULATORY AGENCIES? Some people worry that the regulatory agencies responsible for monitoring all these aspects of our lives - and more - are being influenced by industries, and that this influence enables industries to benefit in some way to the public's detriment. This is what political scientists call 'regulatory capture'. If a government institution has been 'captured', then a particular sector of society (usually a private industry) has excessive influence over the regulatory agency, and so is able to control the decisions made. "This means that captured government institutions do not work in the interests of us all, but only for the benefit of a particular group in society, such as a particular company or a whole industrial sector," explains Eva.

A theoretical example of capture would be a regulatory agency that does not stop the sale of a dangerous product because of industry influence. The company producing the product wants to make more money by continuing to 



\section{ABOUT POLITICAL SCIENCE}

Do you sometimes think about the Prime Minister and what he/she does to serve the public? Do you remember highly charged election campaigns? Or maybe you think about a politician who has been in the news recently. These are all aspects of politics, and are the parts we hear most about in the media. But politics is about so much more than government ministers and elections. Politics covers all aspects of how governments work, from how and why laws are created, to different types of government systems and international relationships between countries. Political scientists are the researchers who study these different aspects of politics.

\section{COMPARATIVE PUBLIC POLICY}

Eva is a political scientist specialising in comparative public policy. "Public policies have a huge impact on us all on a daily basis, yet the nitty gritty details of how policies are made are often ignored in public discussion because they are overshadowed by the drama of political elections and big speeches," she says. "I think the study of public policy and regulation is incredibly important if we want to understand what effects government has on society, and why."

The 'comparative' aspect is because Eva compares public policies across different systems and institutions to help understand what makes some policies work and others fail. By studying policies used in different countries, governments can learn which methods are most successful, and may adopt policies used elsewhere. "The COVID pandemic is a very good example of this," says Eva, "because we are seeing many comparisons of policies to curb the spread of the virus across different countries, which can help us to understand what the most effective tools are."

\section{WHAT ROLE DO POLITICAL}

SCIENTISTS PLAY?

The research conducted by political scientists often influences policies as the results from their work may be used by politicians, civil servants and industries. This is important because academic research is needed to provide the evidence on which good public policies are based.

"The fantastic thing about an academic career in politics is that you can truly follow your passion and study what interests you," says Eva, "be it why governments are so ineffective at tackling climate change, the role of protest movements such as Black Lives Matter in politics, or something else altogether." But political scientists do not just work as academics within universities. There is also a need for political scientists in civil service roles, as researchers for think tanks and for positions in local government.

Is there a policy that you disagree with? Do you think that an area of the government could be improved? If so, perhaps a career in political science will enable you to bring about a positive change for the country.

\section{EXPLORE A CAREER IN POLITICAL SCIENCE}

YouthPolitics UK (www.youthpolitics.org.uk) is a nonprofit organisation that aims to give the young a voice, and the Political Studies Association (www.psa.ac.uk) brings together all political scientists in the UK and provides resources for anyone interested in politics.

If you pursue an academic career in politics, your average salary will be around $£ 41,000$.

If you are interested in becoming politically active, you can join your local branch of a political party.

\section{EVA'S TOP TIPS}

01 Follow your passion.

02 Read and write about your interests as much as possible.

03 Don't be afraid to engage your teachers in conversations about the ideas that fascinate you.

\section{PATHWAY FROM SCHOOL TO POLITICAL SCIENCE}

\section{At school, taking politics, history, economics or sociology classes will be good preparation for a career in politics or political science, though as Eva says, "most subjects have relevance for politics." \\ Most universities offer degrees in politics, political science or international relations.}

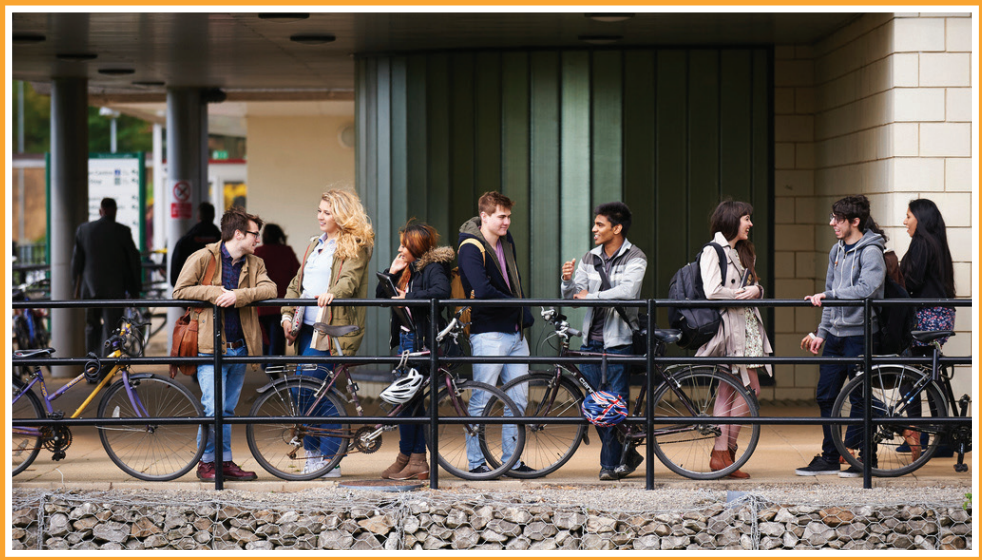

Students at the University of York Library. Credit: University of York, John Houlihan 


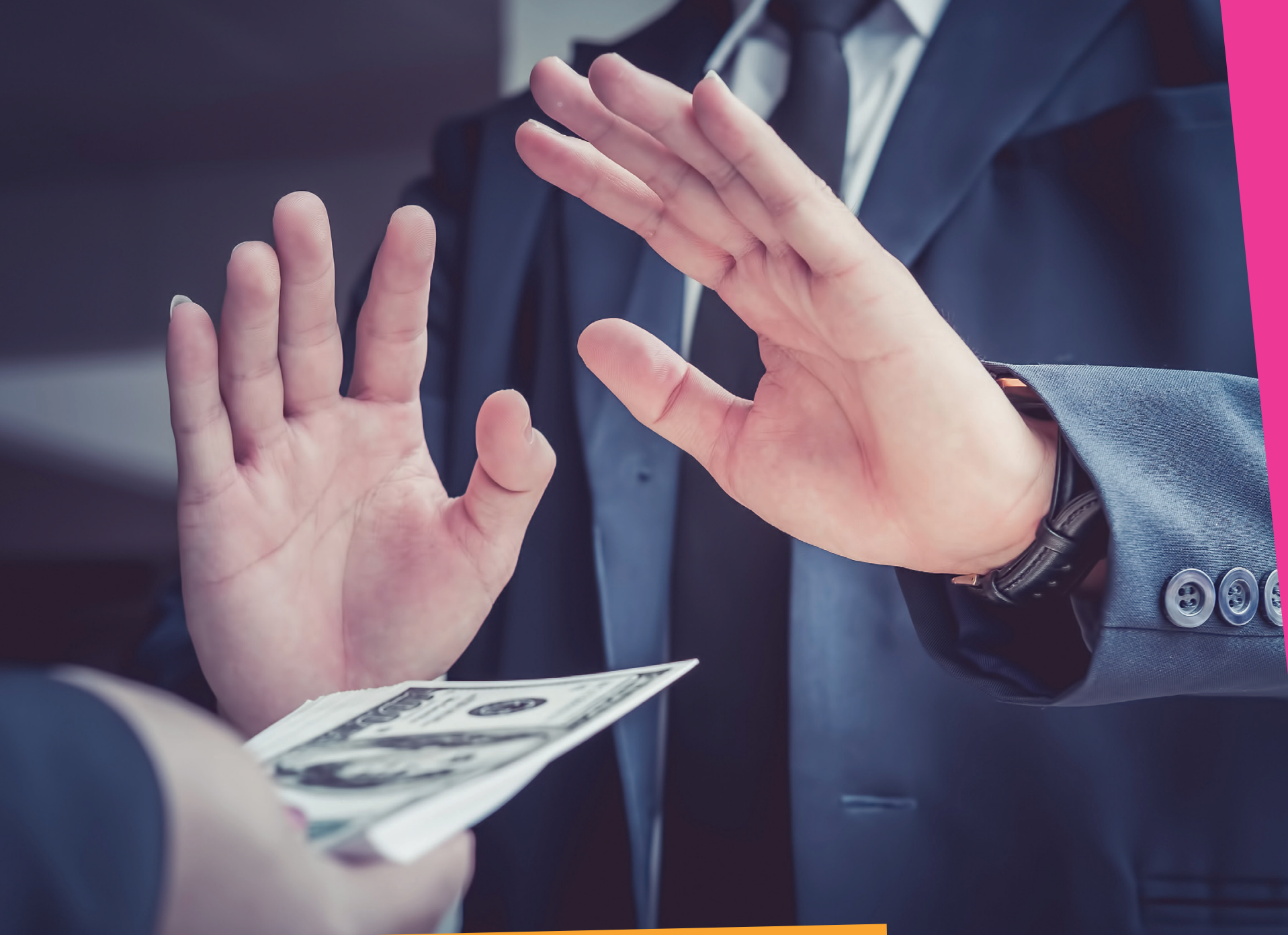

○ HOW DID EVA BECOME
A POLITICAL SCIENTIST?

HAVE YOU ALWAYS BEEN

\section{POLITICALLYMINDED?}

I think so. As long as I can remember, l've always been interested in what is happening in our societies and why. I think that interest was first sparked by concerns about animal welfare when I was a child and what was being done about it, and it developed from there.

YOU HAVE A BA, MSC AND PHD IN POLITICS. WHO OR WHAT INSPIRED YOU TO FOLLOW A CAREER IN THIS FIELD?

I would like to be able to say that one person or event inspired me, and that I always knew that I would follow this path, but that would not be true at all! I think at every step of the way, I met new friends and teachers who inspired me to take the next step. Without the encouragement and support of my teachers and professors along the way, I would not have managed to continue on this path.
WERE YOU INVOLVED IN POLITICAL ACTIVITIES WHEN YOU WERE

\section{YOUNGER?}

As a child, I was very concerned about the environment and endangered species (especially whales) and I founded a local youth group under the wings of Greenpeace. I think that was my earliest experience of being politically and societally engaged.

AS A 'COMPARATIVE' POLITICAL SCIENTIST, DO YOU FIND YOURSELF COMPARING SERVICES OR

PRODUCTS IN OTHER AREAS OF YOUR LIFE?

Yes, for better or worse, it seems to be an occupational hazard! If I'm honest, I probably do this in all areas of my life, but sometimes it would be better not to spend so much time comparing restaurants before you choose which one to go to!
DO YOU THINK THE GENERAL

PUBLIC IS BECOMING MORE OR LESS ENGAGED IN POLITICS?

We went through a long period of people becoming politically disengaged from the 1990 s onwards. But over the past five to ten years, many people have become engaged in politics. While it is good that people take more of an interest in politics now, the situation we now face is still very problematic because opinions are so polarised (think of Brexit in the UK or 'Trumpism' in the US). People on every 'side' are just talking to themselves and are completely dismissing the viewpoints of their 'opponents'. For democratic politics to stay healthy, we need more genuine debate between different viewpoints and a willingness to engage with each other. 